\title{
Overview on Recent PVT Systems with Jet Impingement
}

\author{
Win Eng Ewe ${ }^{1 *}$, Ahmad Fudholi ${ }^{1,2}$, Kamaruzzaman Sopian ${ }^{1}$, Nilofar Asim ${ }^{1}$, Yoyon Ahmudiarto ${ }^{2}$, Agus Salim ${ }^{2}$ \\ ${ }^{1}$ Solar Energy Research Institute, Universiti Kebangsaan Malaysia, 43600 UKM Bangi, Selangor, Malaysia \\ ${ }^{2}$ Research Centre for Electrical Power and Mechatronics, National Research and Innovation Agency Republic of Indonesia \\ (BRIN) Bandung, Indonesia
}

Corresponding Author Email: p97455@siswa.ukm.edu.my

https://doi.org/10.18280/ijht.390633

Received: 28 September 2021

Accepted: 13 December 2021

\section{Keywords:}

photovoltaic, solar collector, jet impingement, heat transfer, cooling

\begin{abstract}
Jet impingement cooling has been utilized to improve the performance of solar energy technologies such as solar collectors, PV systems, PVT systems, and CPV systems. This article provides an overview of current PVT systems using jet impingement. The distinctions between each study, such as research results and PVT system design, are examined and contrasted. The summary demonstrates that solar collectors are the most widely utilized solar energy technology owing to their direct manufacture. There are 20 solar collector studies, 5 for photovoltaic, 9 for photovoltaic thermal, and 8 for concentrator photovoltaic. Geometric characteristics such as jet diameter, spacing, and nozzle height are critical for maximum performance. Furthermore, numerous kinds of coolant jets, such as air, water, and nanofluid, may be seen from the overview. Hybrid systems, such as PVT or CPVT systems, perform better since they create thermal and electrical energy. As a result, more research into developing the hybrid system is advised.
\end{abstract}

\section{INTRODUCTION}

Natural resources, such as fossil fuels used to generate energy, have increased in value due to human activity during the past decade. As a result, many environmental issues have arisen due to industrialization [1]. Renewable energy sources, such as solar energy, may be utilized instead of fossil fuels to produce clean, long-lasting power, preserve energy, and reduce the detrimental effect of the construction industry on global warming and climate change [2].

One of the essential variables in maximizing cell efficacy is the cooling of the PV structure. The efficiency of the commercial PV cells ranges between 12 and $25 \%$. This is because the remaining portion of the radiation converts to thermal energy, raising the cell's temperature. Temperature increases produce a loss in sheet efficiency owing to opencircuit voltage, and increasing temperature decreases load characteristics [3]. Besides, the thermal efficiency of solar air heaters is typically low due to the low convective heat transfer coefficient between the absorber plate and the coolant, such as air, which raises the absorber plate temperature, resulting in higher heat losses to the ambient and low thermal efficiency of such collectors [4]. Therefore, heat must be transmitted effectively to improve the thermal and electrical performance of such collectors. According to research, releasing a directed fluid against a heat-transmitting surface may effectively transfer a considerable quantity of thermal energy and mass between the surface and the fluid. Compared to conventional convection cooling by confined flow parallel to (under) the cooled surface, jet impingement produces heat transfer coefficients that are up to three times higher because the impingement boundary layers are much thinner. Furthermore, after impingement, the spent fluid frequently turbulent the surrounding fluid [5]. This paper will concentrate on the developments in cooling approaches using jet impingement in PVT systems.

\section{SOLAR COLLECTOR}

Solar collectors are a significant component of a solar water heating or air heating system, and they are divided into nonconcentrating and concentrating collectors. Flat plate solar air collectors (SAC) are the most common solar collectors due to their simple manufacture. The collection box, absorber plate, and glass cover are the three most essential components of a flat plate SAC. The first glazed jet impingement solar air collector was constructed in ref. [6], showing that adding a jet air impingement mechanism may improve the maximum thermal efficiency of a flat plate SAC by up to $26.5 \%$. Solar thermal researchers have since explored different integrating solar collectors with jet impingement. As a result, 20 of the 34 selected studies looked at solar collectors using jet impingement. Table 1 shows the list of solar collectors using jet impingement.

Ribs and fins were attached to absorber plates to study SAC [7-14]. The ribs may be installed on either the top or bottom of the absorber plate. Matheswaran et al. [7] suggested the use of arc-shaped wires connected to the top side of the absorber plate. These wires provide artificial roughness and interfere with the formation of laminar sub- layers. As a result, heat transmission between the cooling fluid and the absorber plate rises, and the system's thermal performance improves. Moshery et al. [8] proposed an absorber plate with bottom cylinder transverse ribs. Another design of SAC was suggested by attaching hemispherical protrusion and internal conical ring barriers at the absorber plate's bottom [9, 10]. Absorber plates having arc-shaped transverse ribs and numerous $\mathrm{V}$-shaped ribs at the 
bottom was investigated [11-13]. Goel et al. [14] added longitudinal fins to the absorber plate's bottom. At a Reynolds number of 15,000 , the application of continuous longitudinal fins on the bottom of the absorber plate improves heat transfer by 1.4-1.5 times over jet plate heat transfer and roughened solar air heater. In contrast, the corresponding percentages of heat transfer enhancement are $39 \%$ and $28 \%$, respectively. The attachment of ribs and fins is required to increase the overall surface area of the absorber plate for cooling and improve heat transmission between the cooling fluid and the absorber plate. The introduction of fins enhances heat transmission by expanding the heat transfer area. By adding fins or other roughness geometries over the absorber, the hydraulic diameter of the airflow channel is reduced, boosting air velocity approaching the absorber surface. It also benefits raising air velocity towards the absorber surface [15].

Table 1. Solar collectors using jet impingement

\begin{tabular}{|c|c|c|c|}
\hline Year & Reference & Study & Implemented Approaches \\
\hline 2018 & [7] & Theoretical & $\begin{array}{l}\text { Arc-shaped wires connected to the top } \\
\text { side of the absorber plate }\end{array}$ \\
\hline 2021 & [8] & $\begin{array}{l}\text { Theoretical and } \\
\text { Experimental }\end{array}$ & $\begin{array}{l}\text { Applied transverse ribs on the bottom } \\
\text { part of the absorber plate } \\
\text { Investigate internal conical ring }\end{array}$ \\
\hline 2020 & [9] & Experimental & $\begin{array}{c}\text { obstacles in an impinging jet solar air } \\
\text { heater passage }\end{array}$ \\
\hline 2020 & {$[10]$} & Experimental & $\begin{array}{l}\text { Jet impingement on a hemispherical } \\
\text { protrusion on a heated surface }\end{array}$ \\
\hline 2019 & [11] & Experimental & $\begin{array}{l}\text { Attached multi V-shaped protrusion ribs } \\
\text { on the absorber plate }\end{array}$ \\
\hline 2018 & [12] & Experimental & $\begin{array}{l}\text { The PSI technique was used to optimize } \\
\text { the characteristics of single arc } \\
\text { protrusion ribs in a solar air heater with } \\
\text { impinging air jets }\end{array}$ \\
\hline 2017 & [13] & Experimental & $\begin{array}{l}\text { Attached multiple arc protrusion } \\
\text { obstacles on the absorber plate }\end{array}$ \\
\hline 2017 & [14] & $\begin{array}{l}\text { Theoretical and } \\
\text { Experimental }\end{array}$ & $\begin{array}{l}\text { Attached longitudinal fins with different } \\
\text { fin spacing at the rear part of the } \\
\text { absorber plate }\end{array}$ \\
\hline 2020 & {$[16]$} & $\begin{array}{l}\text { Theoretical and } \\
\text { Experimental }\end{array}$ & $\begin{array}{c}\text { Impinging jet double pass solar air } \\
\text { heater with wavy corrugated plate with } \\
\text { porous } \\
\text { media at air channel }\end{array}$ \\
\hline 2017 & [17] & Experimental & Corrugated absorber plate \\
\hline 2018 & [18] & Theoretical & $\begin{array}{l}\text { Solar air collector with slit-perforated } \\
\text { corrugated plate }\end{array}$ \\
\hline 2016 & [19] & $\begin{array}{l}\text { Theoretical and } \\
\text { Experimental }\end{array}$ & $\begin{array}{l}\text { Investigate perforating corrugated plate } \\
\text { in a glazed transpired solar collector }\end{array}$ \\
\hline
\end{tabular}

$2016 \quad$ [20] Theoretical

$2017 \quad$ [21] Experimental

$2020 \quad[22] \quad$ Theoretical

$2017 \quad$ [23] Experimental

2017 [24] Experimental

2016 [25] Experimental

2016 [26] Experimental

2017 [27] Theoretical
Proposed a hybrid micro-channel, pillar, and jet with heat sink

Investigate the effect of angle of attack and jet diameter

CFD simulation study on the effects of jet diameter and height ratio on the solar air heater with jet impingement

Optimization of a solar thermal collector with jet air impingement

Study the performance of an inline jet plate solar air heater

Optimization of the solar thermal collector with jet air impingement

The impact of flow and channel spacings, Z1 and Z2, on a cross-flow staggered hole jet plate solar air heater performance were investigated.

Design a CFD model of a stationary water-spray cleaning system for concentrated solar thermal reflector
Research Findings

Max exergy efficiency of $4.36 \%$ obtained

Max thermal efficiency is $78 \%$

Conical ring obstacles induce multiple swirl flow inside the collector and increase the rate of heat transfer

The highest thermohydraulic performance parameter obtained was 3.01

The highest thermohydraulic performance parameter obtained was 3.44 .

1.1 relative height ratios, 10 relative pitch ratios, $60^{\circ}$ angle of arc, 0.4 streamwise variations, and 0.85 spanwise variations are the optimum parameters

5 relative width ratio, 1 relative height ratio, 9.5 relative pitch ratio, and $55^{\circ}$ angle of arc are the optimum parameters

Max thermal efficiency is $61 \%$, with fin spacing $1 \mathrm{~cm}$

Max thermal and thermohydraulic efficiencies are $94 \%$ and $84 \%$

The proposed design has $14 \%$ higher performance than smooth duct

Effective efficiency reached a maximum of $67.83 \%$.

The thermal efficiency drops as the inlet temperature, collector width, and porosity rise, increasing when the ambient air temperature, radiation intensity, and collector height increase.

Hybrid designs with low jet pitch to jet diameter ratios achieved high heat transfer coefficients, while hybrid designs achieved low-pressure drops with high jet pitch to jet diameter ratios.

A maximum thermal enhancement factor of 2.19 and an efficiency of $55.8 \%$ are achieved.

0.065 jet diameter ratio and 0.216 jet height ratio are optimum parameters for the best performance.

The performance was enhanced by $48.3 \%$ at optimal settings of parameters

Max performance obtained at jet diameter to hydraulic diameter ratio of 0.07

The optimal configuration of the parameters obtained at streamwise pitch ratio of 0.435 ; spanwise pitch ratio of 0.869 ; jet diameter ratio of $0.065 ; 16,000$ Reynolds number

The proposed design has higher thermal efficiency than the conventional solar collector

Optimal standoff distance ranges of 5-26 outlet nozzle diameter 
A wavy corrugated absorber plate is used in the research to enhance the overall surface area for cooling and heat absorption of $[16,17]$. Perforated corrugated plate was utilized as an absorber plate to increase the heat collecting area and strengthen the jet impingement $[18,19]$. Husain et al. [20] encased micro-channels and pillars on the absorber plate's bottom to enhance cooling fluid flow. Yadav et al. used a flat absorber plate and a typical jet impingement arrangement [22]. Various jet designs were emphasized in [21, 23-26], whereas Anglani et al. [27] does not illustrate absorber plate design.

\section{PHOTOVOLTAIC}

Thermal management is a crucial factor influencing the overall performance of solar systems, especially in hot climate nations where the solar irradiance retains higher, such as Malaysia, India, and Indonesia. This phenomenon enhances the temperature rising of the PV module, which leads to decreasing electrical efficiency [28]. As a result, the cooling approach is recommended to keep the cell at working temperature and should be such that it retains the average cell temperature at a minimum with a uniform distribution. 5 of the 34 research looked at photovoltaic (PV) systems. Jet impingement is being investigated for use in PV systems due to its potential cooling capabilities compared to traditional cooling techniques. The cooling system is often installed towards the bottom of the PV panel or cells to avoid shadows and maximize light absorption by the PV cells at the front. However, Alghamdi et al. [29] put the jet impingement cooling system in front of the PV panels to clean and eliminate dust.

PV cells come in various shapes and sizes, including monocrystalline silicon cells, polycrystalline silicon cells, thin-film cells, and multi-junction cells. Due to the various material combinations that convert more incoming light energy to electricity, multi-junction cells have the highest efficiency (35\%) of the four kinds. The cells are made the same way as thin-film cells, although they are more complex and costly to produce. Monocrystalline cells are composed of silicon that has been formed as a single crystal with an internal structure that is continuous. This silicon is produced into a large cylindrical ingot and then thinly sliced to create wafer cells, often dark blue or black. These manufacturing methods use much more resources than polycrystalline cells, resulting in a little higher cost but a slightly better efficiency (20\%). Polycrystalline cells are created by fusing silicon crystal fragments. This fabrication requires fewer resources to manufacture and has advanced to the point where the efficiency and performance of a polycrystalline panel are similar to those of a monocrystalline panel $(16 \%)$ but at a little lower cost. Thin film technology makes solar cells out of different materials such as silicon, cadmium, and copper. Thin-film modules, which may be rigid or flexible, enable more seamless integration of solar energy into goods and structures than crystalline silicon. Thin-film solar panels are no longer available in most countries because of their higher cost and lower efficiency (11\%) than contemporary mono and polysilicon panels. Bahaidarah [30] utilized monocrystalline solar cells; Alghamdi et al. used polycrystalline solar cells [29, 31]; and Abou-Ziyan et al. [32, 33] used multi-junction solar cells in this research.

\section{PHOTOVOLTAIC THERMAL}

PVT collectors combine photovoltaic solar cells, which convert sunlight to electricity, with a solar thermal collector, which transports waste heat from the photovoltaic module to a heat transfer fluid. These technologies may achieve higher overall efficiency than photovoltaic or solar thermal alone because they integrate energy and heat production inside a single component. 9 of the 34 research looked at PVT systems using jet impingement. Table 2 shows a list of the PVT systems using jet impingement.

Table 2. PVT systems using jet impingement

\begin{tabular}{|c|c|c|c|c|}
\hline Year & References & Study & Implemented Approaches & Research Findings \\
\hline 2018 & {$[34]$} & Theoretical & PVT with a water jet & $\begin{array}{l}\text { Max thermal, PV, and total efficiencies } \\
\text { are } 72 \%, 11.35 \% \text {, and } 81 \%\end{array}$ \\
\hline 2018 & {$[35]$} & Theoretical & CPC-PVT with a water jet & Improving electrical efficiency by $7 \%$ \\
\hline 2017 & {$[36]$} & Experimental & PVT with nanofluids jet & $\begin{array}{c}\text { Max thermal, PV, and total efficiencies are } \\
\qquad 85 \%, 12.75 \% \text {, and } 97.75 \% .\end{array}$ \\
\hline 2019 & {$[37]$} & Theoretical & $\begin{array}{l}\text { Integrate high concentrator triple-junction solar } \\
\text { cell with hybrid jet impingement/microchannel }\end{array}$ & $\begin{array}{l}\text { Achieved max electrical efficiency of } \\
39.7 \% \text { and exergy efficiency of } 53.5 \%\end{array}$ \\
\hline 2018 & {$[38]$} & Experimental & $\begin{array}{l}\text { Investigate four various types of jet impingement } \\
\text { heat sinks with triple-junction solar cell }\end{array}$ & Achieved max exergy efficiency of $53.25 \%$ \\
\hline 2020 & {$[39]$} & Experimental & $\begin{array}{l}\text { Investigate the performance of a CPV with a novel } \\
\text { jet impingement mini and microchannel heat sink } \\
\text { with a heat spreader }\end{array}$ & $\begin{array}{l}\text { Achieved } 14.3 \% \text { electrical efficiency with } \\
\text { 35.4W net power }\end{array}$ \\
\hline 2020 & {$[40]$} & Experimental & $\begin{array}{l}\text { Integrate Gallium Arsenide cell with carbon } \\
\text { nanotube nanofluid microchannels }\end{array}$ & $\begin{array}{l}\text { Carbon nanotube nanofluids have more } \\
\text { excellent thermal conductivity than } \\
\mathrm{SiO}_{2} / \text { water nanofluids, and the thermal } \\
\text { conductivity of nanofluids increases with } \\
\text { mass fraction and temperature }\end{array}$ \\
\hline 2019 & [41] & Theoretical & $\begin{array}{c}\text { Compare dish concentrator and plane-mirrors } \\
\text { array concentrator }\end{array}$ & Max electrical efficiency is $25 \%$ \\
\hline 2021 & {$[42]$} & Experimental & Introduces Bifacial PVT with jet air impingement & $\begin{array}{l}\text { Max thermal and electrical efficiencies are } \\
51 \% \text { and } 10.7 \%\end{array}$ \\
\hline
\end{tabular}

For their experiment, Hasan et al. utilize standard polycrystalline PV panels with 36 cells measuring 156 X 156 $\mathrm{mm}$ in size [34-36]. The PV panel is $1490 \mathrm{~mm}$ in length and
$675 \mathrm{~mm}$ in breadth. Abo-Zahhad et al. suggested a 'triplejunction solar cell in this research is constructed of $\mathrm{GaInP} / \mathrm{GaInAs} / \mathrm{Ge}$ and has an active area of $11 \mathrm{~cm}^{2}$ and a 
typical electrical efficiency of $40.3 \%$ under a concentration ratio (CR) 1000x $\left(x=1000 \mathrm{~W} / \mathrm{m}^{2}\right)^{\prime}[37,38]$. Awad et al. [39] utilized a polycrystalline solar cell with a $12.5 \mathrm{~cm}$ square area. Zhang et al. [40] demonstrated a triple-junction gallium arsenide cell with length, breadth, and height of $10.1 \mathrm{~mm}$, $10.8 \mathrm{~mm}$, and $0.195 \mathrm{~mm}$, respectively. Chen et al. [41] did not specify the size of the PV panel or the number of PV cells utilized in the research. In Ref. [42], a monocrystalline bifacial PV panel is used in the investigation.

\section{CONCENTRATOR PHOTOVOLTAIC}

Concentrator photovoltaics (CPV) (also known as concentration photovoltaics) is a photovoltaic technology that generates sunlight. Unlike conventional photovoltaic systems, it uses lenses or curved mirrors to focus sunlight onto tiny, highly effective multi-junction (MJ) solar cells. Consequently, high-concentration photovoltaic (HCPV) systems offer the most outstanding efficiency of any current PV technology, with manufactured modules reaching $40 \%$ at Concentrator Standard Test Conditions (CSTC) and approaching 30\% of commercially available CPV module efficiencies [43]. In order to optimize efficiency, CPV systems typically include sun trackers and, in certain instances, a cooling system. A total of 8 investigations were conducted from the 34 combined PV or PVT systems with concentrators.

Abou-Ziyan et al. conducted computational analyses of photovoltaic concentrator systems (CPV) $[32,33]$. Therefore, the design of the technique of the concentrator is absent from the research. The concentration ratios used in the investigations ranged from 250 to 2250 . The findings demonstrated that a more excellent concentration ratio would boost energy production and net output power. Jaaz et al. [35] described compound parabolic concentrated (CPC) PVT but did not specify the concentration ratio tested. Besides, researchers $[37,38]$ employed a Fresnel lens and a parabolic dish solar concentrator system, respectively, to obtain a 1000x $\left(x=1000 \mathrm{~W} / \mathrm{m}^{2}\right)$ concentration ratio. Another study in [39] also carried out numerical studies with concentration ratios ranging from 5 to 20. The system's optimal performance can be observed at the greatest concentration ratio, which is 20 . In Ref. [40], a Fresnel three-stage concentrator was applied with a fixed concentration ratio for their CPVT studies.

Chen et al. [41] developed a dish concentrator and a planemirrors array concentrator with concentration ratios of 200 , 368 , and 450. The system's most outstanding thermal efficiency is $55 \%$ at concentration ratios of 450 , while its highest electrical efficiency is $26 \%$ at concentration ratios of 200. High thermal efficiency can be achieved when the concentrator correctly tracks the sunlight using a two-axis tracking mechanism. The focal point of the concentrator generates a high energy flux density and raises the surface temperature of the receiver. However, according to the research, higher concentration ratios improve thermal performance and degrade a PVT system's electrical performance. Hence, the concentration ratios should be set accordingly to the desired output, whether the thermal or electrical output is prioritized.

\section{CONCLUSION}

Jet impingement cooling mechanism has been used to enhance the performance of solar energy technologies, such as solar collector, PV, PVT, and CPV systems. In this article, an overview of recent PVT systems with jet impingement is conducted. The differences between each research, such as research findings and design of the PVT system, are discussed and compared. The overview reveals that solar collectors are the most used solar energy technologies due to their more accessible and non-complex construction. There are 20 studies related to the solar collector, 5 for photovoltaic, 9 for photovoltaic thermal, and 8 for concentrator photovoltaic (Table 3). The geometric configurations such as jet diameter, jet spacing, and nozzle height are crucial parameters for optimum performance. Besides, different types of coolant jet can be observed from the overview, for example, air, water, and nanofluid. Hybrid systems such as PVT or CPVT systems demonstrate higher performance as they simultaneously generate thermal and electrical energy. Hence, further investigation on the development of the hybrid system is recommended.

Table 3. Types of solar energy technologies using jet impingement

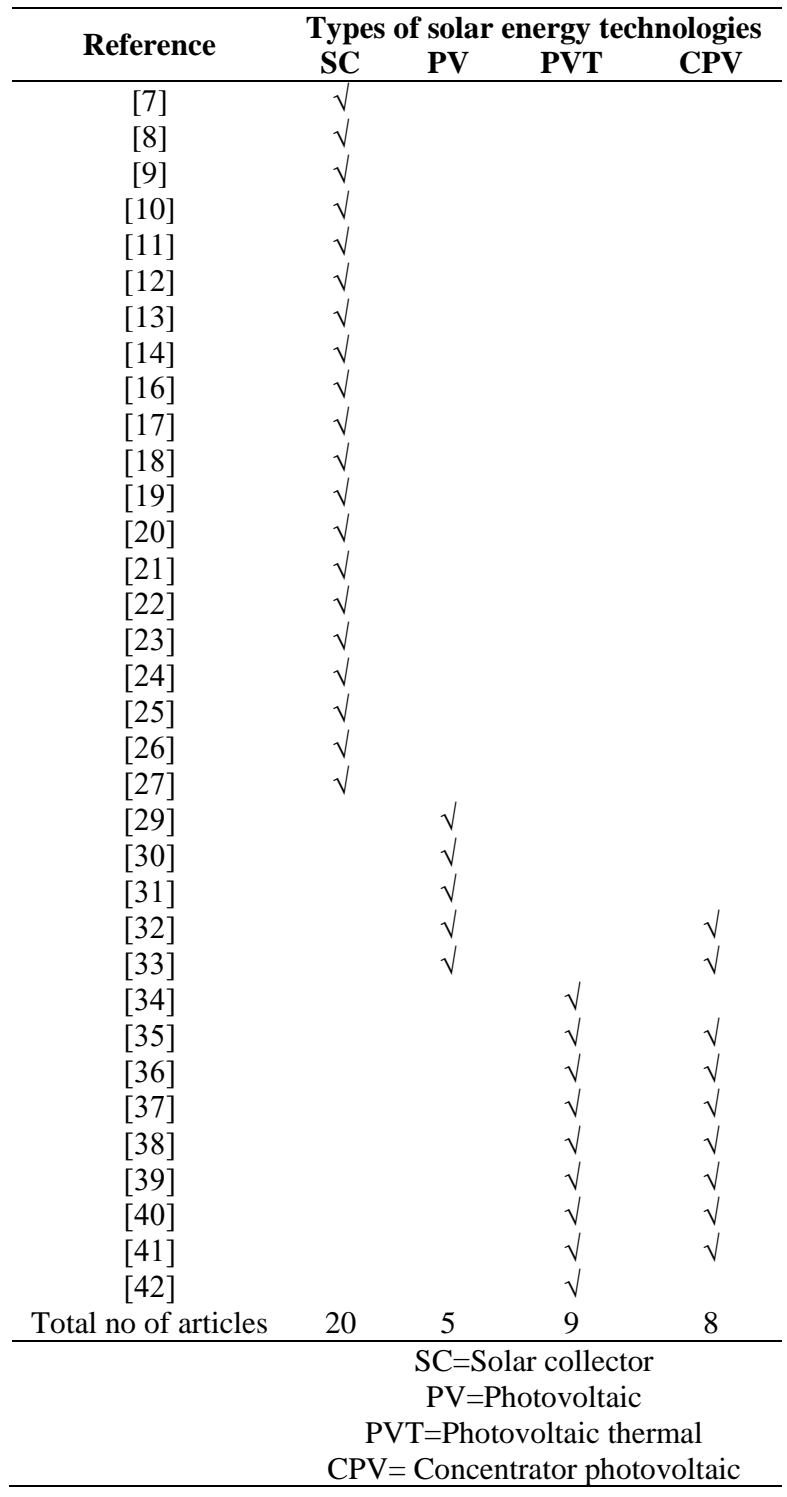

\section{REFERENCE}

[1] Good, C. (2016). Environmental impact assessments of hybrid photovoltaic-thermal (PV/T) systems-A review. 
Renewable and Sustainable Energy Reviews, 55: 234239. https://doi.org/10.1016/j.rser.2015.10.156

[2] Ewe, W.E., Fudholi, A., Sopian, K., Asim, N. (2019). Evaluation of solar air collector-thermoelectric hybrid system. Journal of Advanced Research in Fluid Mechanics and Thermal Sciences, 59(1): 142-147.

[3] Brideau, S.A., Collins, M.R. (2014). Development and validation of a hybrid PV/Thermal air based collector model with impinging jets. Solar Energy, 102: 234-246. https://doi.org/10.1016/j.solener.2014.01.022

[4] Karwa, R., Chauhan, K. (2010). Performance evaluation of solar air heaters having $\mathrm{V}$-down discrete rib roughness on the absorber plate. Energy, 35(1): 398-409. https://doi.org/10.1016/j.energy.2009.10.007

[5] Chauhan, R., Thakur, N.S. (2013). Heat transfer and friction factor correlations for impinging jet solar air heater. Experimental Thermal and Fluid Science, 44: 760-767.

https://doi.org/10.1016/j.expthermflusci.2012.09.019

[6] Choudhury, C., Garg, H.P. (1991). Evaluation of a jet plate solar air heater. Solar Energy, 46(4): 199-209. https://doi.org/10.1016/0038-092X(91)90064-4

[7] Matheswaran, M.M., Arjunan, T.V., Somasundaram, D. (2018). Analytical investigation of solar air heater with jet impingement using energy and exergy analysis. Solar Energy, 161: 25-37. https://doi.org/10.1016/j.solener.2017.12.036

[8] Moshery, R., Chai, T.Y., Sopian, K., Fudholi, A., AlWaeli, A.H. (2021). Thermal performance of jetimpingement solar air heater with transverse ribs absorber plate. Solar Energy, 214: 355-366. https://doi.org/10.1016/j.solener.2020.11.059

[9] Kumar, N., Kumar, A., Maithani, R. (2020). Development of new correlations for heat transfer and pressure loss due to internal conical ring obstacles in an impinging jet solar air heater passage. Thermal Science and Engineering Progress, 17: 100493. https://doi.org/10.1016/j.tsep.2020.100493

[10] Maithani, R., Kumar, A., Raghav, G., Nagpal, M., Kumar, B. (2021). Thermal analysis of jet impingement on hemispherical protrusion on heated surface. Experimental Heat Transfer, 34(7): 662-677. https://doi.org/10.1080/08916152.2020.1808117

[11] Kumar, R., Nadda, R., Rana, A., Chauhan, R., Chandel, S.S. (2020). Performance investigation of a solar thermal collector provided with air jets impingement on multi $\mathrm{V}$ shaped protrusion ribs absorber plate. Heat and Mass Transfer, 56(3): 913-930 https://doi.org/10.1007/s00231-019-02755-2

[12] Nadda, R., Kumar, R., Kumar, A., Maithani, R. (2018). Optimization of single arc protrusion ribs parameters in solar air heater with impinging air jets based upon PSI approach. Thermal Science and Engineering Progress, 7: 146-154. https://doi.org/10.1016/j.tsep.2018.05.008

[13] Nadda, R., Kumar, A., Maithani, R. (2017). Developing heat transfer and friction loss in an impingement jets solar air heater with multiple arc protrusion obstacles. Solar Energy, 158: 117-131. https://doi.org/10.1016/j.solener.2017.09.042

[14] Goel, A.K., Singh, S.N. (2019). Performance studies of a jet plate solar air heater with longitudinal fins. International Journal of Ambient Energy, 40(2): 119-127. https://doi.org/10.1080/01430750.2017.1372808

[15] Vengadesan, E., Senthil, R. (2020). A review on recent developments in thermal performance enhancement methods of flat plate solar air collector. Renewable and Sustainable Energy Reviews, 134: 110315. https://doi.org/10.1016/j.rser.2020.110315

[16] Singh, S., Chaurasiya, S.K., Negi, B.S., Chander, S., Nemś, M., Negi, S. (2020). Utilizing circular jet impingement to enhance thermal performance of solar air heater. Renewable Energy, 154: 1327-1345. https://doi.org/10.1016/j.renene.2020.03.095

[17] Aboghrara, A.M., Baharudin, B.T.H.T., Alghoul, M.A., Adam, N.M., Hairuddin, A.A., Hasan, H.A. (2017). Performance analysis of solar air heater with jet impingement on corrugated absorber plate. Case Studies in Thermal Engineering, 10: 111-120. https://doi.org/10.1016/j.csite.2017.04.002

[18] Zhang, H., Ma, X., You, S., et al. (2018). Mathematical modeling and performance analysis of a solar air collector with slit-perforated corrugated plate. Solar Energy, 167: 147-157. https://doi.org/10.1016/j.solener.2018.04.003

[19] Zheng, W., Li, B., Zhang, H., You, S., Li, Y., Ye, T. (2016). Thermal characteristics of a glazed transpired solar collector with perforating corrugated plate in cold regions. $\quad$ Energy, 109: 781-790. https://doi.org/10.1016/j.energy.2016.05.064

[20] Husain, A., Ariz, M., Al-Rawahi, N.Z., Ansari, M.Z. (2016). Thermal performance analysis of a hybrid microchannel, -pillar and -jet impingement heat sink. Applied Thermal Engineering, 102: 989-1000. https://doi.org/10.1016/j.applthermaleng.2016.03.048

[21] Rajaseenivasan, T., Prasanth, S.R., Antony, M.S., Srithar, K. (2017). Experimental investigation on the performance of an impinging jet solar air heater. Alexandria Engineering Journal, 56(1): 63-69. https://doi.org/10.1016/j.aej.2016.09.004

[22] Yadav, S., Saini, R.P. (2020). Numerical investigation on the performance of a solar air heater using jet impingement with absorber plate. Solar Energy, 208: 236-248. https://doi.org/10.1016/j.solener.2020.07.088

[23] Chauhan, R., Singh, T., Kumar, N., Patnaik, A., Thakur, N.S. (2017). Experimental investigation and optimization of impinging jet solar thermal collector by Taguchi method. Applied Thermal Engineering, 116: 100-109.

https://doi.org/10.1016/j.applthermaleng.2017.01.025

[24] Soni, A., Singh, S.N. (2017). Experimental analysis of geometrical parameters on the performance of an inline jet plate solar air heater. Solar Energy, 148: 149-156. https://doi.org/10.1016/j.solener.2017.03.081

[25] Nayak, R.K., Singh, S.N. (2016). Effect of geometrical aspects on the performance of jet plate solar air heater. Solar Energy, 137: 434-440. https://doi.org/10.1016/j.solener.2016.08.02

[26] Chauhan, R., Singh, T., Thakur, N.S., Patnaik, A. (2016). Optimization of parameters in solar thermal collector provided with impinging air jets based upon preference selection index method. Renewable Energy, 99: 118-126. https://doi.org/10.1016/j.renene.2016.06.046

[27] Anglani, F., Barry, J., Dekkers, W. (2017). Development and validation of a stationary water-spray cleaning system for concentrated solar thermal (CST) reflectors. Solar Energy, 155: 574-583. https://doi.org/10.1016/j.solener.2017.06.013

[28] Tripanagnostopoulos, Y., Nousia, T.H., Souliotis, M., 
Yianoulis, P. (2002). Hybrid photovoltaic/thermal solar systems. Solar Energy, 72(3): 217-234. https://doi.org/10.1016/S0038-092X(01)00096-2

[29] Alghamdi, A.S., Bahaj, A.S., Blunden, L.S., Wu, Y. (2019). Dust removal from solar PV modules by automated cleaning systems. Energies, 12(15): 2923. https://doi.org/10.3390/en12152923

[30] Bahaidarah, H.M. (2016). Experimental performance evaluation and modeling of jet impingement cooling for thermal management of photovoltaics. Solar Energy, 135: 605-617. https://doi.org/10.1016/j.solener.2016.06.015

[31] Javidan, M., Moghadam, A.J. (2021). Experimental investigation on thermal management of a photovoltaic module using water-jet impingement cooling. Energy Conversion and Management, 228: 113686. https://doi.org/10.1016/j.enconman.2020.113686

[32] Abou-Ziyan, H., Ibrahim, M., Abdel-Hameed, H. (2020). Characteristics enhancement of one-section and twostepwise microchannels for cooling high-concentration multi-junction photovoltaic cells. Energy Conversion and Management, 206:112488. https://doi.org/10.1016/j.enconman.2020.112488

[33] Abou-Ziyan, H., Ibrahim, M., Abdel-Hameed, H. (2020). Performance modeling and analysis of highconcentration multi-junction photovoltaics using advanced hybrid cooling systems. Applied Energy, 269: 115060. https://doi.org/10.1016/j.apenergy.2020.115060

[34] Hasan, H.A., Sopian, K., Fudholi, A. (2018). Photovoltaic thermal solar water collector designed with a jet collision system. Energy, 161: 412-424. https://doi.org/10.1016/j.energy.2018.07.141

[35] Jaaz, A. H., Sopian, K., Gaaz, T.S. (2018). Study of the electrical and thermal performances of photovoltaic thermal collector-compound parabolic concentrated. Results in Physics, 9: 500-510. https://doi.org/10.1016/j.rinp.2018.03.004

[36] Hasan, H.A., Sopian, K., Jaaz, A.H., Al-Shamani, A.N. (2017). Experimental investigation of jet array nanofluids impingement in photovoltaic/thermal collector. Solar Energy, 144: 321-334. https://doi.org/10.1016/j.solener.2017.01.036

[37] Abo-Zahhad, E.M., Ookawara, S., Radwan, A., ElShazly, A.H., Elkady, M.F. (2019). Numerical analyses of hybrid jet impingement/microchannel cooling device for thermal management of high concentrator triplejunction solar cell. Applied Energy, 253: 113538. https://doi.org/10.1016/j.apenergy.2019.113538

[38] Abo-Zahhad, E.M., Ookawara, S., Radwan, A., ElShazly, A.H., ElKady, M.F. (2018). Thermal and structure analyses of high concentrator solar cell under confined jet impingement cooling. Energy Conversion and Management, 176: 39-54. https://doi.org/10.1016/j.enconman.2018.09.005

[39] Awad, M., Radwan, A., Abdelrehim, O., Emam, M., Shmroukh, A.N., Ahmed, M. (2020). Performance evaluation of concentrator photovoltaic systems integrated with a new jet impingement-microchannel heat sink and heat spreader. Solar Energy, 199: 852-863. https://doi.org/10.1016/j.solener.2020.02.078

[40] Zhang, H., Yan, S., Wang, T., Wu, Y., Zhao, X., Zhao, N. (2020). Enhanced heat transfer of carbon nanotube nanofluid microchannels applied on cooling gallium arsenide cell. Journal of Thermal Science, 29(6): 14751486. https://doi.org/10.1007/s11630-020-1303-5

[41] Chen, H., Li, G., Yang, J., Zhang, F., Liang, M., Ji, J. (2019). Experimental and comparison study on two solar dish systems with a high concentration ratio. Journal of Thermal Science, 28(6): 1205-1211. https://doi.org/10.1007/s11630-019-1104-X

[42] Ewe, W.E., Fudholi, A., Sopian, K., Asim, N. (2021). Modeling of bifacial photovoltaic-thermal (PVT) air heater with jet plate. International Journal of Heat and Technology, https://doi.org/10.18280/ijht.390409

[43] Wiesenfarth, W., Philipps, S.P., Bett, A.W., Horowitz, K., Kurtz, S. (2017). Current status of concentrator photovoltaic (CPV) technology Version 1.3. Fraunhofer Institute for Solar Energy Systems ISE: Freiburg, Germany. 